\title{
Labour and Segmentation in Value Chains
}

\author{
Nikolaus Hammer \\ School of Management, University of Leicester, nh80@le.ac.uk \\ Lone Riisgaard \\ Institute for Society and Globalisation, Roskilde University, loner@ruc.dk
}

The appeal of the GVC approach to labour process research consists in its explanatory framework of the relations between firms and workers in a global division of labour. So far, however, a substantial integration of the two approaches has proved difficult as GVC analysis has primarily been concerned with the impact of different forms of GVC governance and has largely neglected the contested nature of the labour process as well as labour markets. Over the last years, a number of researchers have tried to address this gap and have gone beyond a concern with labour as an input factor.

While differences exist across GVC perspectives (Gibbon et al, 2008), debates on the social embeddedness of GVCs (Bair, 2008; Palpacuer, 2008; Coe et al, 2008) have helped recognising labour as a collective actor trying to shape the entry barriers of value chains through, for example, social and labour standards, as well as an agent in the very process of production. Geographers and development scholars (e.g. Barrientos et al, 2003; Lund and Nicholson, 2003; Henderson et al, 2002) and, more recently, labour process and industrial relations scholars have begun to widen notions of labour in GVCs and started to 'put labour into value chains' (e.g. Taylor et al, 2013).

The case for integrating GVC analysis with labour has been made with regard to different areas of work and employment as well as from different theoretical premises: regarding the role of social institutions and skill formation (Ramirez and Rainbird, 2010); inter-firm 
relations and employment relations (Lakhani et al, 2013); space and embedded production networks (Rainnie et al, 2011). This chapter builds on these debates. Yet, rather than starting from the impact of governance on work and employment, its entry point lies in an acknowledgement of the interdependencies of the social relations at the workplace and GVCs, thereby aiming to highlight how the labour process and the social relations in which they are embedded impact on GVCs. The argument put forward here is that, while market and coordination structures within GVCs are relevant, it is the indeterminacy of labour (its social and political intractability as a production factor) that is fundamental when it comes to explaining agency at various levels within GVCs. It is important to note that different strands of value chain analysis (e.g. Gibbon et al, 2008) are, implicitly or explicitly, based on different concepts of labour and the labour process. For example, the global production networks perspective (e.g. Coe et al, 2008) is explicit in viewing labour as a contested social relation and the basis of value creation; our discussion below, however, focuses on what might be called the GVC mainstream (as in Gereffi et al, 2005) which looks at labour, skills, and employment as input factors.

In this chapter, we emphasise two aspects of contemporary factory regimes that help to underscore the importance of a broad perspective on the labour process and social relations of production, as well as their role for GVC dynamics. First, there is a wide range of production relations that have been brought into the centre of GVCs - from formal employment to informal outwork to dependent self-employment (Chen, 2005; Barnes, 2012). The restructuring of GVC governance has not only affected how different production relations and factory regimes are coordinated or compete across the global economy. Rather, it is the outcomes of GVC restructuring and struggles at the point of 
production that have restructured and re-segmented those production relations and factory regimes themselves. Increasingly, the same product can, for example, be produced by formal and informal employees as well as casual and day labourers working side by side in an exporter's production facilities, as outwork/homework, or by independent informal 'entrepreneurs', who often are own account workers who neither own their means of production, nor the production inputs. Second, in analysing the role of the labour process within GVCs, it is important to bring in the social relations those labour processes draw on: how, for example, the increasing informalisation of formal employment, particular forms of worker mobility, and the autonomy of workers over their own reproduction are part of the struggles over the extraction of labour from labour power. These social relations not only give a concrete form to the indeterminacy of labour but also to the methods of control within the labour process. And beyond their role in the extraction of labour from labour power, these social relations shape notions of solidarity and forms of collective action, and, in this process, generate renewed dynamics of GVC restructuring.

Three areas, we argue, need to be recognised in particular, in making the social relations under which value is produced and distributed more explicit. First, an emphasis on the indeterminacy of labour recognises that the purchase of labour power alone does not secure a predefined quality and quantity of labour, and that the latter needs to be extracted through ever-contested mechanisms of control (e.g. Thompson and Newsome, 2004). This inherent contestation at the point of production accords the labour process a relative autonomy from market (and GVC) structures. Second, building on such a concept of the labour process, we need to recognise that the outcomes of management-labour relations have implications for dynamics of cooperation and competition between firms, 
as well as between different groups of workers or different production relations. Thus, struggles between management and labour at the workplace impact on the dynamics of segmentation in, both, product as well as labour markets (Grimshaw and Rubery, 2005). Third, we feel it is useful to expand the notion of factory regimes not only by a recognition of the role of the employment contract (Nichols and Cam, 2005) but also by relations of reproduction as elements of particular solidary, gender and migration regimes are reconfigured into GVCs.

The chapter proceeds in two parts. The first section discusses some of the elements that link the labour process with the broader political economy. It takes up arguments from within labour process theory about moving 'beyond skills and control' or even 'beyond the workplace' and argues how the contingent nature of workplace struggles influences the configuration of labour and product markets. The second section shows how GVC restructuring, while deriving advantages from relocation and outsourcing, also entails a considerable re-segmentation of the workforce along the lines of the employment contract, worker mobility, and the living arrangements of workers. Thus, what labour process theory offers to GVC analysis, is a concept of GVCs that links different labour processes, production relations as well as factory regimes. It is only through recognition of the contingent nature of workplace dynamics as well as their wider social relations that we can flesh out specific forms of GVCs' social and institutional embeddedness (Bair, 2008; Taylor, 2010; Selwyn, 2013).

\section{The Labour Process, Power, and Governance}


The emphasis GVC analysis placed on different forms of inter-firm governance has become a focus of critique and has been countered by calls to socially 'embed' GVCs and to 'bring the social back in' (Bair, 2008; Palpacuer, 2008). In the first instance, the problem with GVC analysis is less that work and employment, or labour as an agent, do not figure but that the workplace only figures as a dependent variable that absorbs the constraints stemming from particular forms of governance. This treatment of labour highlights the paradox that forms of inter-firm governance are seen as socially constructed, yet that the very processes through which the actors within the firm are constituted, are neglected. We argue, in a first step, that the indeterminacy of labour and the specific workplace dynamics that arise out of that are central in fleshing out this social, and therefore contested, embeddedness of GVCs. The acknowledgement of the interdependencies between the social dynamics at the workplace and market dynamics allows developing accounts of the changing division of labour and associated organisational forms that draw on politics and power rather than notions of efficiency (as is the case when forms of governance are seen as a function of the complexity and costs of the transaction between firms; e.g. Gereffi et al, 2005).

Approaches that have a conception of the contested nature of the labour process have for some time tried to analyse its implications beyond the workplace, that is, for the labour and product market. The common assumption in those approaches is that the contestations over the labour process (over the extraction of labour from labour power as well as mechanisms of control) have consequences for workers and employers with regard to their respective abilities to compete in labour and product markets as well as regarding their ability to organise collectively. Different authors within the labour process 
tradition have conceptualised this link between the workplace and product market competition in different ways, by emphasising their contingent relations (Edwards, 1986; Brown, 2008) or by conceiving of them as part of a circuit of capital (Kelly, 1985). While these arguments, as we will see below, do not differentiate between horizontal and vertical forms of competition, and thereby do not say much about the functional division of labour, their basic point should also hold for forms of cooperation and competition across GVCs. Thus, struggles over the labour process, as they underlie both the balance of power at the workplace as well as that of organised actors, shape not only how firms compete in product markets but also the way they can build their forward and backward linkages or pursue strategies of industrial upgrading.

Brown (2008) and Edwards (1986), for example, have both insisted on the indeterminate and interdependent nature of the links between product markets, technology and work organisation. While workplace struggles take place under constraints set by product markets and technology, they "develop logics of their own" and result in collective organisation that is able to challenge "some of the 'external' conditions of its activity..." (Edwards 1986, 275). Historically, workplace struggles have established public goods (e.g. in the form of collective bargaining that underlies industrial peace and the sharing of productivity gains) and thereby shaped the organisation of production and product markets (Brown 2008).

While this argument shows how labour process dynamics can shape product markets, Kelly (1985) has argued from a Marxist perspective that the analysis of the labour process needs to go beyond the capital-labour relationship and that the real subordination of labour is not solely achieved through control in the labour process. Kelly's point is 
that, rather than examining particular factors impacting on the labour process, it is important to analyse the articulation of different parts within the circuit of capital.

"To account for observed changes in the division of labour we must ... consider the possible role of competition between capitals, as well as conflict between labour and capital. ... we need to consider the full circuit of industrial capital as the starting point for analyses of changes in the division of labour: purchase of labour power; extraction of surplus value within the labour process; realisation of surplus value within product markets. There is no sound theoretical reason for privileging one moment in this circuit the labour-capital relation within the labour process - if our objective is to account for changes (or variations) in the division of labour.” (Kelly, 1985, 32)

The indeterminacy of labour also underlies approaches of labour market segmentation that tried to spell out the resulting dynamics across capital-labour, capital-capital, and labour-labour relations (Rubery, 2007). Looking at work and employment from an interorganisational perspective, Grimshaw and Rubery (2005), for example, argue that product market competition puts constraints on management at the same time as, in reverse, workers' strategies have important implications for product market dynamics. As differences within labour have an immediate impact on the competitive relations between different capitals it is difficult to confine the analysis of the employment relationship to a management-labour issue on the wage-effort bargain, separate from inter-capital relations. In a labour market segmentation perspective, organisational change and the dynamics of the employment relationship are intricately related: 
"since, as organisations adapt their boundaries, new tensions and contradictions between capital (the contracting organisations) and labour (the different workforces) arise that, in turn, may act as a brake on organisational change or a pressure for further transformation and diffusion.” (Grimshaw and Rubery, 2005, 1038)

The core assumptions of labour process theory as well the analysis beyond the workplace are important not only insofar as they place capital-labour relations in a broader political economy but also because they offer an analytical foundation for social- and power-based explanations of market structures, competitive dynamics, and ultimately also of value chain governance. Restructuring processes within the global economy clearly impact on the way production and labour processes are organised, yet, as production is fragmented, labour processes are broken up and re-linked, workforces re-segmented, and new contradictions emerge for management. Compromises over the labour process coconstitute the range of strategies firms can reasonably pursue within the functional division of labour, in specific product markets, as well as in labour markets. Given the way they rest on the labour process, firms' competitive strategies are as unstable and inherently contested as the former.

GVC analysis has looked at changing forms of economic coordination primarily from the angle of value chain or inter-firm governance, that is, forms of coordination across the functional division of labour or forms of inter-firm coordination beyond market and hierarchy. Insofar as relations between firms occupy centre stage, the approach privileges a firm-centric (Selwyn, 2013) and managerial perspective. This leaves two options for the way labour is conceived: either it is at the receiving end of major restructuring processes such as changing trade policies or the rise of buyer-driven GVCs that affect work and 
employment, or it appears as a stakeholder/campaigner in exactly those restructuring processes. Either way, strategies of control and resistance over the labour process (that is, the contested nature of value production) are not part of value chain analysis.

A strong formulation that looks more to transaction cost- rather than power-based explanations of value chain governance can be found in Gereffi et al (2005) where different forms of governance are developed on the basis of the following dimensions: the complexity of transactions, the ability to codify those transactions as well as the capabilities in the supply base. Against this framework, however, it can be argued that organisational or strategic change, is part and parcel of management and there is no reason to assume that the labour process and workplace relations are neutral as regards different forms of governance. In fact, it might be difficult to argue that the labour process and the organisation of work have no bearing on the complexity of transactions, the ability to codify those transactions as well as the capabilities in the supply base. Lakhani et al (2013) have aimed to bring these implications to the fore more explicitly with regard to employment relations but remain too close to the transaction cost foundations of this approach to grant a fundamental role to social struggles at or around the workplace.

In contrast, there is a growing sense that the contested nature of workplace relations and the labour process, as the locus where labour is extracted, is important in explaining the dynamics of GVC restructuring. For example, when Barrientos and Kritzinger (2004) discuss the increase in contract labour in the South African fruit export sector as it became more integrated into GVCs, they also point to the downsides the externalisation of employment can have on the labour process: "Problems can arise ... given the producer 
is less able to control skill, incentives, commitment or employment conditions of contract workers to meet the quality standards set by global buyers." (Barrientos and Kritzinger 2004, 84) Thus, drawing on Kelly's circuits of capital framework one might say that the requirements of buyer-driven value chain governance can create problems in the labour process that, ultimately, might lead to a disarticulation between the GVC and the labour process.

The arguments presented above show how a labour process perspective allows broadening our concepts of cooperation, coordination, competition, and control within GVCs beyond a focus on firm networks in the functional division of labour. The struggles over the labour process, that is, over the organisation of production, over productivity and quality, over management's control strategies, over labour's resistance, etc., are central for the way firms compete and position themselves within a value chain. The articulation of the labour process with those product and process standards through which governance is exerted is contingent on the social relations at work. In other words, the ability of employers to manage the indeterminacy of labour establishes their competitive bid, regarding firms in the same sector as well as access to the functional division of labour, in the first place. However, as Burawoy's factory regimes as well as feminist work would have it, struggles over the extraction of labour extend to terrains beyond the workplace.

In fact, the second step of our argument on the interdependencies between the labour process and GVCs is to highlight not only the work intensification and increasing segmentation of the workforce within the labour process but also the extent to which a range of factory regimes in the Global South are defined by a weakening of established 
protections in terrains outside the workplace. For example, it can often be observed that management strategies in the context of GVC restructuring create complex divisions: between groups of workers performing the same tasks (establishing different 'tiers', Barrientos 2013); between those performing different aspects of the labour process (what would conventionally fall under segmentation); as well as between different relations of production. Such lines of division often overlap, for example when formal and informal employees work side by side, and allow us to return to the two aims introduced in the beginning. First, the reconfiguration of GVCs underlies the fragmentation of production and re-segmentation of production relations in a range of inter-linked labour processes (e.g. Basole and Basu 2011 on India). Second, management mobilises aspects such as contract, mobility, and reproduction as controlling devices in such inter-linked labour processes. Those dimensions thereby constitute important terrains on which GVCs' factory regimes compete. In discussing these aspects in more detail below with regard to GVCs, we find it useful to look at Burawoy’s factory regimes (1985), Smith's division between the effort-wage bargain and the effort-mobility bargain (2006) as well as the work of ethnographers and development researchers on informal employment (e.g. Breman 2010).

\section{The Fragmentation of Production and the Segmentation of Workers}

The restructuring of global value chains highlights a range of interlinked processes of differentiation. First, the fragmentation of production resets the basis on which different labour processes are linked and compete with each other; second, such changes often 
come with a re-segmentation of the workforce insofar as upgrading or outsourcing pose new competitive challenges and focus on reorganising the relevant labour processes; third, as management responds to GVC restructuring, we can observe a 'tiering' of the workforce within the firm whereby workers essentially perform equivalent tasks, yet are divided by a range of different employment statuses (Barrientos 2013). On the one hand, these different aspects of GVC restructuring indicate how it is socially and politically contested at the workplace. For example, as captive arrangements between firms and cost pressures become stronger, firms may refocus their core activities, intensify the labour process, and change the composition and terms of their workforce. However, the viability of this form of governance is dependent on the social relations and resistance at work, as well as the extent to which the organisation of the labour process can be successfully articulated with labour and product markets, as well as the functional division of labour. On the other hand, the fragmentation of production highlights strategies of control in restructured labour processes that go far beyond the fairly regulated terrain of the workplace and the employment relationship of the Global North. While GVC analysis promises a perspective on how different labour processes are re-combined across global value chains, such insights have been hampered by narrow concepts of work, employment, and the broader social relations they are embedded in (Taylor 2010). In this respect, research from labour process, anthropological and feminist perspectives have been able to open up important questions around work and household production (Yeates 2004), migration and informalisation (Breman 2010) or role of work space-living space linkages in the formation of solidarities and collective action (Jenkins 2013; Hammer 
2010). In the following sections we discuss such extension with regard to contract, living arrangements, and mobility.

\section{Contract and the employment relationship}

Efforts to externalise labour and to weaken the institutions of hegemonic factory regimes that supported labour's bargaining power at the workplace can be broken down into three different moments of segmentation and tiering: along a range of precarious employment contracts; on the basis of different production relations; as well as through the supply and management of labour through third party labour contractors. These elements have become central features in factory regimes of the Global South.

Exploring labour control in factory regimes of the Global South, Nichols and Cam (2005) build on Burawoy's concept of factory regimes but highlight the specific role different forms of material support and contract play in the segmentation of the workforce. This contrasts with the support afforded through a range of welfare benefits in hegemonic regimes. On the one hand, it concerns the role of firm-level provisions in "employees' subordination, making them dependent on the enterprise welfare system for housing, pensions, sickness benefits, and so on." (Burawoy 1985, 144). On the other hand, the increasing segmentation of the workforce according to different contracts is linked back to aspects of material support and reproduces divisions. Examples can be found in the way contractual status gives access to housing, or paternalist contributions to health and industrial accident costs, or even the education of workers' children.

Nichols and Cam $(2005,222)$, in their study of the global white goods industry, found that, as regards labour control, elements of the "ideological apparatus of hegemonic 
despotism are well in place, [yet] ... the dismantling of established labour is also well under way". This is expressed in reductions of relatively privileged workers in favour of more precarious contracts or outsourcing, as well as a reduction in the (historically often fairly considerable) material support. They conclude on an interesting note that underlines the variation in management strategies as well as the forms of managementlabour accommodations at the workplace: whereas factories in China, Taiwan and South Korea have seen a rapid and massive shift towards fixed-term and agency labour, the overwhelming part of the workforce in Turkish and Brazilian white goods factories remained on permanent contracts. In the context of a global industry, this suggests a certain autonomy of the labour process; in consequence such differences are relevant in firms' competitive positioning in product markets as well as value chains.

This emphasis on workforce segmentation on the basis of a range of 'non-standard' contracts corresponds with concerns to differentiate between different production relations that has come out of research on the informal economy (see e.g. Chen 2005; Barnes 2012). Against the background of an increasing informalisation of formal employment, it is crucial to distinguish independent forms of self-employment from those that are based on the authority relations of an employment relationship; to distinguish between different forms of informal employment; as well as to analyse the deeply gendered nature of the informal economy (e.g. Chen 2005). Even in MNCs' subsidiaries (rather than any outsourced production units) we can observe a strongly segmented and tiered order, observed, for example in Hammer's (2010) study on MNCs in Greater Delhi. These cases showed that beneath a small layer of permanent employees existed a tier of so-called apprentices. These apprentices were essentially fully skilled migrant 
workers who, through this classification, were denied the wage rates, the employment security as well as the status that come with permanent employment within an MNC. Further sources of flexibility stemmed from segments of so-called 'contract workers' (in fact, outsourced workers), 'company casuals' as well as casual employees. The last three tiers represented informal employees, with 'company casuals' effectively constituting a labour pool that could count on more regular opportunities than casual employees.

A crucial contribution of these debates on informality lies in their relational treatment of informal employment which emphasises the complex dynamics between informal and other forms of employment, the discontinuous character of informal employment, and the way it operates around regulated economic activity (Harriss-White and Gooptu 2001; Agarwala 2009; Breman 2010). Crucially, it locates informality in the context of contemporary forms of economic organisation and management strategies:

"In contrast to definitions based on modernisation and neoliberal assumptions, a relational definition does not view the informal economy as an isolated remnant of a feudal past that will automatically disappear under the market influence of industrialisation. ... Once such interdependencies between the informal economy, formal economy, the state, and civil society are unearthed, the relational definition can be operationalised to include the entire range of informal workers." (Agarwala 2009, 336)

Another important aspect of the shift towards 'non-standard employment' lies in the increasing mediation of employment through 'third party labour contractors'. In this case, the risk that is displaced through the outsourcing of production is paralleled through the outsourcing of different aspects of the management of labour which can combine internal 
and externalised functions in different ways. Barrientos (2013), for example, brings this out clearly, differentiating between different labour intermediaries depending on the extent to which they perform functions of supplying, paying, supervising labour. These dynamics result in a situation where the workforce is not only segmented but also 'tiered' in that workers on different contracts perform the same tasks next to each other.

Returning to our theme of the interdependencies between the labour process, product markets and the functional division of labour, one can see how multiple lines of segmentation and 'tiering' might weaken labour's influence, particular in the way market pressures underlie hegemonic despotic factory regimes. However, a factory regime built on such fine divisions might be difficult to sustain, and be inherently unstable, when it comes to articulating the labour process with quality standards in GVCs.

\section{Living conditions}

Differentiations along contractual lines are often closely paralleled by access to a continuum of more or less coercive and decent living conditions. They reinforce control at the workplace in different ways at the same time as they give rise to particular forms of resistance: depending on the context, labour camps or compounds at the same time are a site of control as well as a terrain to organise labour process resistance. The politics around living arrangements are closely intertwined with those over mobility choices which we will discuss below, however, they deserve to be kept analytically separate.

In a study on the development of the compounds in the South African mining industry Bezuidenhout and Buhlungu (2011) present a useful differentiation of aspects of control: spatial control, reproductive control, associational control and political control. This 
related to restrictions on the movement of workers as they migrate as well as how they can move around compounds and the adjacent localities; the institution of single-sex compounds as well as the firm's monopoly on selling provisions; the regulation of union and other associational activities amongst workers; as well as the policing and coercive side of mining firms' control over workers and their living areas. During the mid-1980s, however, a combination of factors such as mounting international pressure, a high gold price as well as changes in the labour process, led to more formalised industrial relations and allowed the National Union of Mineworkers (NUM) to organise the compounds and, subsequently, organise collective discipline during strikes. As established forms of control were transformed in the transition to post-apartheid South Africa, though, living areas have spread geographically and become more segmented as the "company-state is making way for the market as the key mechanism of control. The logic of coercion is fading, and the logic of choice intersects with class and citizenship status." (Bezuidenhout and Buhlungu 2011, 254) Needless to say that these developments have challenged the foundational solidarities of NUM's power. Interestingly, the combination of market control with segmentation along class, ethnicity, caste, citizenship lines is a central organising logic of living areas in hegemonic despotism as it entrenches the link between 'promotion' in the contractual hierarchy at work and an 'upgrading' in living arrangements.

Differences across forms of dormitory labour regimes or constellations between work and living spaces need to be recognised and, following Pun and Smith (2007), it is instructive to link these arrangements, both, to societal aspects as well as the functional division of labour. While there is no mechanistic correspondence between dormitory labour regimes 
and the position in the value chain, there are clear interdependencies between the labour process, the forms of control within living arrangements, and the drivenness of global value chains (and therefore the visibility and political opportunities afforded by those living arrangements). The state, clearly, is an important actor in the regulation as well as provision of living arrangements and communal services (or the withdrawal from social protection as detailed in Pun et al 2010). Where workers have little leverage at the workplace they at times see the state as a target for class-based demands that are expressed as improvements in living conditions, a social wage and expanded forms of citizenship (e.g. Agarwala 2009).

\section{Mobility}

Against the background of capital mobility in the restructuring of global value chains, it is probably surprising that the mobility of labour has received relatively scant attention, particularly in the construction or hospitality sectors where migrant labour constitutes the reverse of offshoring. However, going beyond the specific mobility form of labour migration, labour process theory has integrated mobility into the core of its considerations. Central here is Smith's (2006) differentiation of two aspects of the indeterminacy of labour: while the effort-wage bargain is concerned with the extraction of labour from labour power in the labour process, what he calls the effort-mobility bargain is concerned with the substitutability of labour and the ownership over mobility choices. Even though mobility within the capitalist employment relationship is owned by the worker, employers can use a range of strategies in order to influence actual mobility choices. 
Management strategies over recruitment, contracts, and living arrangements all come together in segmenting and tiering the workforce and in structuring the labour process. For example, in his research on labour in South and South-East Asia Breman (2010) shows how the informalisation of labour is developed and reproduced through mechanisms of circular migration. In such a regime, employers in quarries or the textile industries in Western India preferred hiring migrant workers from far-away regions despite an oversupply of labour in their own region. In turn, workers from those regions had to look elsewhere for their survival. In this process, mobility and recruitment on the base of ethnic or caste lines combine to structure the workforce into fragmented solidarities and collectivities. At a different level, research on Indian construction sites has also pointed to the practice of rotating groups/gangs of workers around sites in order to prevent the formation of strong social contacts and collective organisation. Rather than being the outcome of supply and demand factors on the labour market, these processes are the result of changing social relations of production in the wake of the expulsion of rural landless/land-poor labour, the integration into global value chains, as well as the resegmentation of product and labour markets through outsourcing.

As argued above, mobility choices can be shaped in a number of ways as well as in different directions. At the workplace level, workers are often tied-in/locked-in through advance payments, at times through withheld wages or the confiscation of identity and/or residency documents. Breman (2010, 343-345), for example, argues that forms of debt bondage are shaped by capitalist relations rather than earlier forms of servitude in the sense that neo-bondage is governed through a contract dominated by its economic dimension (for 2005 he estimates that 40 million workers are caught in such relations of 
unfree labour in India). Neo-bondage has developed as a genuine social relation in the emergence of the market-based political economy and therefore cannot be seen as a residual of earlier forms of agrarian bondage. Neo-bondage is based on the migrant, ethnic, caste, and gender relations that inform the segmentation of the labour force, and is overlaid by the contractual cascades of which labour contractors are a central part of (Barrientos 2013). However, depending on the power balance at work and the wider labour market, such devices can also be turned into their opposite. For example, underlining the point about capitalist forms of neo-bondage, Breman (2010) reports an instance where workers originally were tied-in through advance payments. As skilled labour became scarce, though, and the power balance between employers and workers shifted, these advance payments came to be seen as a sunk cost to the employer, and effectively became a 'signing-on fee'.

In many cases, the structure of mobility choices and the particular strategies they are based on are supported by the state insofar as they directly result from regulatory gaps and inconsistencies. For example, both for migrants from former Soviet republics to Russia as well as internal migrants in China, the regulated relation between work, social protection, and residency permits established a more or less grey or illegal space, severely restricting or even abolishing workers mobility choices (HRW; Pun et al 2010). The few examples given above should also sharpen our perspectives to forms of neobondage and their relationship with other segments of the workforce. Equally, at the core of Smith's (2006) distinction between two aspects of the indeterminacy of labour, lies an appreciation that struggles within the labour process are interdependent with the ownership over mobility choices. In the same sense, the extent to which labour is 
substitutable in the restructuring of GVCs and the particular forms such struggles can take, needs to be recognised.

\section{Conclusion}

GVC analysis has paid considerable attention to the determinants of value chain governance and has, in the process, focused on transactions between firms at the expense of the struggles over the labour process that are at the basis of any transaction. Referring back to labour process debates, this chapter has argued that conflict at the point of production cannot be reduced to a management-labour issue alone but that it has implications for the structure of labour and product markets too. In the same way, the labour process, it is argued, is not trivial with regard to firms' positioning within the functional division of labour. The ability to organise the labour process is crucial not only for firms' vertical and horizontal competitiveness but also for their ability to develop inter-firm cooperations. The restructuring of GVCs breaks up labour processes but immediately reconnects them through struggles at the workplace level and the implications they have for labour and product markets. A conception of value chains as interlinked sets of horizontally and vertically competing labour processes can play an important part in a social explanation of GVC dynamics.

The chapter has also argued that GVC restructuring has led to an expansion of the terrains of control strategies of the labour process beyond the workplace. The fragmentation of labour processes has come with complex forms of tiering and/or segmenting workforces along precarious employment contracts and different forms of 
informal employment, the structuring of mobility choices, and living arrangements.

These terrains of control are a systemic element of the way GVCs are reorganised: they form part of the social foundations on which Taylorist and flexible forms of production are recombined and reconnected in GVCs (Pun and Smith 2007). While there is space for more detailed analyses of the interrelations between the fragmentation of production processes, the internal tiering of the workforce, and the re-segmentation of the labour market, we feel that they are important elements in a power-based account of GVC restructuring as opposed to one that is based on firm strategy. Furthermore, the focus on the labour process and struggles over control beyond the workplace allows to account for new terrains that shape global forms of economic organisation.

\section{References}

AGARWALA, R. (2009) An Economic Sociology of Informal Work: The Case of India, 315342, in N. Bandelj (ed.) Economic Sociology of Work (Bingley: JAI Press)

BAIR, J., 2008. Analysing Global Economic Organization: Embedded Networks and Global Chains Compared. Economy and Society, 37(3), 339-364.

BARNES, T., 2012. Marxism and Informal Labour. Journal of Australian Political Economy, (No 70), 144-166.

BARRIENTOS, S. and KRITZINGER, A., 2004. Squaring the Circle: Global Production and the Informalisation of Work in South African Fruit Exports. Journal of International Development, 16(1), 81-92.

BARRIENTOS, S., 2013. 'Labour Chains': Analysing the Role of Labour Contractors in Global Production Networks. Journal of Development Studies, 49(8), 1058-1071. 
BARRIENTOS, S., DOLAN, C. and TALLONTIRE, A., 2003. A Gendered Value Chain Approach to Codes of Conduct in African Horticulture. World Development, 31(9), 1511-1526.

BASOLE, A., and BASU, D., 2011. Relations of production and modes of surplus extraction in India: Part II - 'Informal' industry. Economic and Political Weekly, 46(15), April 9, 63-79.

BEZUIDENHOUT, A. and BUHLUNGU, S., 2011. From Compounded to Fragmented Labour: Mineworkers and the Demise of Compounds in South Africa. Antipode, 43(2), 237-263.

BREMAN, J. (2010) Outcast Labour in Asia - Circulation and Informalization of the Workforce at the Bottom of the Economy (New Delhi: Oxford University Press)

BROWN, W., 2008. The Influence of Product Markets on Industrial Relations. In: P. BLYTON, N. BACON, J. FIORITO and E. HEERY, eds, The SAGE Handbook of Industrial Relations. London: Sage, 113-128.

BURAWOY, M., 1985. The Politics of Production. London: Verso.

CHEN, M.A., 2005. Rethinking the Informal Economy: Linkages With the Formal Economy and the Formal Regulatory Environment. http://www.wider.unu.edu/publications/workingpapers/research-papers/2005/en GB/rp2005-

10/ files/78091752824112453/default/rp2005-10.pdf: UNU-WIDER Research Paper $2005 / 10$.

COE, N.M., DICKEN, P. and HESS, M., 2008. Global Production Networks: Realising the Potential. Journal of Economic Geography, 8(3), pp. 271-295.

EDWARDS, P.K., 1986. Conflict at Work. A Materialist Analysis of Workplace Relations. Oxford: Basil Blackwell.

GEREFFI, G., HUMPHREY, J. and STURGEON, T., 2005. The Governance of Global Value Chains. Review of International Political Economy, 12(1), 78-104. 
GIBBON, P., BAIR, J. and PONTE, S., 2008. Governing Global Value Chains: An Introduction. Economy and Society, 37(3), 315-338.

GRIMSHAW, D. and J. RUBERY (2005) Inter-capital relations and the network organisation: redefining the work and employment nexus, Cambridge Journal of Economics 29(6), 10271051

HAMMER, A. (2010), Trade unions in a constrained environment: workers' voices from a New Industrial Zone in India, Industrial Relations Journal, 41(2), pp.168-184

HARRISS-WHITE, B. and N. GOOPTU (2001) Mapping India's World of Unorganized Labour, Socialist Register 37, 89-118

JENKINS, J., 2013. Organising 'Spaces of Hope': Union Formation by Indian Garment Workers. British Journal of Industrial Relations, 51(3), 623-643.

KELLY, J., 1985. Management's Redesign of Work: Labour Process, Labour Markets and Product Markets. In: D. KINGHTS, H. WILLMOTT and D. COLLINSON, eds, Job Redesign. Critical Perspectives on the Labour Process. Aldershot: Gower, 30-51.

LAKHANI, T., KURUVILLA, S. and AVGAR, A., 2013. From the Firm to the Network: Global Value Chains and Employment Relations Theory. British Journal of Industrial Relations, 51(3), 440-472.

LUND, F. and NICHOLSON, J., eds, 2003. Chains of Production, Ladders of Protection. Social Protection for Workers in the Informal Economy. Durban, South Africa: School of Development Studies, University of Natal.

NICHOLS, T. and CAM, S., 2005. Labour in a Global World - Some Comparisons. In: T. NICHOLS and S. CAM, eds, Labour in a Global World: Case Studies from the White Goods Industry in Africa, South America, East Asia, and Europe. Basingstoke: Palgrave Macmillan, 206-238. 
PALPACUER, F., 2008. Bringing the Social Context Back In: Governance and Wealth Distribution in Global Commodity Chains. Economy and Society, 37(3), pp. 393-419. PUN, N. and SMITH, C., 2007. Putting Transnational Labour Process in Its Place: The Dormitory Labour Regime in POst-Socialist China. Work, Employment and Society, 21(1), 27-45.

PUN, N., KING, C.C.C. and CHAN, J., 2010. The Role of the State, Labour Policy and Migrant Workers' Struggles in Globalized China. Global Labour Journal, 1(1), 132-151.

RAINNIE, A., HEROD, A. and MCGRATH-CHAMP, S., 2011. Review and Positions: Global Production Networks and Labour. Competition and Change, 15(2), 155-169.

RAMIREZ, P. and RAINBIRD, H., 2010. Making the Connections: Bringing Skill Formation Into Global Value Chain Analysis. Work, Employment and Society, 24(4), 699-710.

RIISGAARD, L. and HAMMER, N., 2011. Prospects for Labour in Global Value Chains: Labour Standards in the Cut Flower and Banana Industries. British Journal of Industrial Relations, 49(1), 168-190.

ROBINSON, P.K. and RAINBIRD, H., 2013. International Supply Chains and the Labour Process. Competition and Change, 17(1), 91-107.

RUBERY, J. (2007) Developing segmentation theory: a thirty year perspective, Economies et Sociétés, 26(6), 941-964.

SELWYN, B., 2007. Labour Process and Workers' Bargaining Power in Export and Grape Production, North East Brazil. Journal of Agrarian Change, 7(4), 526-553.

SELWYN, B., 2013. Social Upgrading and Labour in Global Production Networks: A Critique and an Alternative Conception. Competition and Change, 17(1), 75-90.

SMITH, C. (2006) The Double Indeterminacy of Labour Power: Labour Effort and Labour Mobility, Work, Employment and Society, 20(2), 389-402 
TAYLOR, P. (2010) The Globalisation of Service Work: Analysing the Transnational Call Centre Value Chain, 244-268, in P. THOMPSON and C. SMITH (eds.) Working Life. Renewing Labour Process Analysis (London: Palgrave Macmillan)

TAYLOR, P., NEWSOME, K. and RAINNIE, A., 2013. 'Putting Labour in its Place': Global Value Chains and Labour Process Analysis. Competition and Change, 17(1), 1-5.

THOMPSON, P. and NEWSOME, K., 2004. Labour Process Theory, Work, and the Employment Relations. In: B.E. KAUFMAN, ed, Theoretical Perspectives on Work and the Employment Relationship. Ithaca/NY: ILR Press, 133-162.

THOMPSON, P. and SMITH, C., 2009. Labour Power and Labour Process: Contesting the Marginality of the Sociology of Work. Sociology, 43(5), 913-930.

YEATES, N., 2004. Global Care Chains. International Feminist Journal of Politics, 6(3), 369391. 